\title{
Ethical Values in Archival Arrangement and Description: An Analysis of Professional Codes of Ethics
}

\author{
Andrieli Pachú da Silva*, José Augusto Chaves Guimarães**, \\ Natália Bolfarini Tognoli*** \\ */**/***Institutional Postal Address: Avenida Hygino Muzzi Filho, 737 - \\ Marília, São Paulo- Brasil - CEP: 17525-000 \\ *<andrielipachu@marilia.unesp.br>,**<guima@marilia.unesp.br>, \\ $* * *<$ nataliatognoli@marilia.unesp.br $>$
}

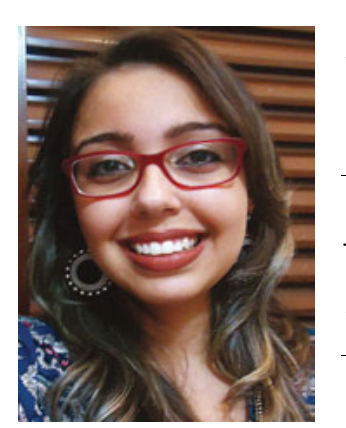

Andrieli Pachu da Silva holds a Bachelor in Archival Science from São Paulo State University (UNESP), Marilia, Brazil. Currently, she is a graduate student in information science and member of the Information Organization Research Group (Formação e Atuação Profissional em Organização da Informação, FAPOI) at the same university.

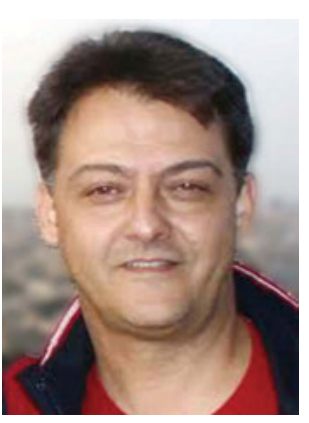

José Augusto Chaves Guimarães is Professor at the Graduate School of Information Science - São Paulo State University - UNESP (Marilia - Brazil). His research and teaching interests are epistemology of knowledge organiziation, knowledge organization ethics, archival knowledge organziation, and domain analysis.

Natália Bolfarini Tognoli is Professor at the Graduate School of Information Science - São Paulo State University - UNESP (Marilia - Brazil). Her research and teaching interests are epistemology of archival science, archival knowledge organization, archival representation and diplomatics.

Pachú da Silva, Andrieli, Chaves Guimarães, José Augusto, Bolfarini Tognoli, Natália. Ethical Values in Archival Arrangement and Description: An Analysis of Professional Codes of Ethics. Knowledge Organization. 42(5), 346-352. 38 references.

\begin{abstract}
The international literature on information science has devoted attention to ethical studies in information, especially due to the development of information technologies. However, the information organization activities have incipient ethical studies that are mostly focused on libraries. Thus, the area of archival science still lacks studies of this nature, which leads to question how the codes of ethics for archivists address issues related to ethical dilemmas of information organization activities, especially in core activities of arrangement and document description. Thus, this study aims to identify and analyze ethical values related to those aforementioned activities, by analyzing the codes of the following countries: Brazil, Portugal, France, Spain, Australia, Canada, USA, New Zealand, United Kingdom and Switzerland and the ICA codes of ethics. Applying a content analysis, the following values were found: access and use, authenticity, confidentiality, conservation, custody, impartiality, information access, information security, physical preservation of the record, reliability, respect for provenance, respect for the original order, respect for the preservation of the archival value of the record.
\end{abstract}

Received: 14 July 2015; Accepted 15 July 2015

Keywords: information, archival description, archival arrangement, archival classification, respect, ethical values

\subsection{Introduction}

The establishment of "organic information" as an object of archival science (Rousseau \& Couture 1988) allowed the improvement of a scientific dialogue between this field and information science. It also supported the conception of archival knowledge organization as a mediator between the knowledge that is produced by society and its use to create new knowledge (Foscarini 2006; Gilliland 2006; Tognoli and Guimarães 2010, 2012; Tognoli, et al. 
2013; Barros and Moraes 2012; Henttonen 2012, 2014; Zhang 2012; Angel 2013; Ribeiro 2014). Therefore, archival knowledge can be regarded as all the knowledge that is contained in the records produced or accumulated by a particular person or entity and grouped together. This is what makes the respect of fonds an inherent attribute (Duchein 1983). Archival knowledge organization has its nuclear activities in arrangement and description (Duchein 1983; Rousseau and Couture 1994; Schellenberg 1996; Thomassen 2001). These two procedures are related not only to the contents that are inherent to them, but also to the professional practice (values and attitudes in the professional action) and its consequences for the users, which reveals an ethical dimension.

According to Guimarães $(2005,6)$, "the object of professional ethics is the set of moral values that a particular professional class should follow to achieve a correct and appropriate professional action to the society in which he/she operates and it is materialized through rules, expressed in codes of ethics, guiding the professional conduct of a specific area." Rego et al. (2014) analyzed the ethical values presented in codes of Associação dos Arquivistas Brasileiros (AAB), International Council of Archives (ICA) and Society of American Archivists, identifying seven values: respect for provenance, integrity of records, impartiality, communication of records, authenticity of records, access and secrecy of records, and professional relationship. In this line, we wonder whether archival professionals are concerned with the "why" and "what for" of the arrangement and description activities, while we also aim to analyze which ethical values are considered by the deontological codes for archivists in an international context regarding the search for correct and appropriate professional conduct.

We analyzed 16 archival codes of ethics available on the Network of Concerned Historians website $(\mathrm{NCH}$, History) for the following countries: Australia, Brazil, Canada, France, New Zealand, Portugal, Spain, Switzerland, United Kingdom, and United States, as well as the International Code of the International Council of Archives. These countries were chosen because of their tradition in archival science and because they represent four continents: the Americas, Europe and Oceania. The corpus was selected by the incidence of terms (archival classification/arrangement, and description) and their correspondents in Spanish, French and Portuguese. We conducted a content analysis (Bardin 1977) on the textual analysis and the results were compared to the categories in Guimarães et al. (2008) regarding the values and ethical problems in knowledge organization and representation (KOR) activities.

\subsection{Archival Arrangement and Description as Nuclear Activities to Archival Knowledge Organization}

The activities of classification/arrangement and description are nuclear to the organization and representation of archival knowledge known as all the knowledge that is contained in the records produced or accumulated by a particular person or entity and grouped together, which is called fonds. In this sense, we understand that the arrangement schemes and finding aids reflect this knowledge.

The classification, according to Sousa $(2007 \mathrm{a}, 6)$, is a matriarchal activity which precedes mainly the evaluation and description activities and, for most authors, it is "a fundamental task, a special moment in the organization process, the first step to give access to information." However, although there is a consensus about the classification activity, we still have to move forward on the subject, once as pointed out by Sousa (2007b), archival science is still not using the contributions of philosophy classification, the theory of classification and the theory of concept, and therefore requires communication with other disciplines that can contribute to the development of the area. Contemporary archival science is concerned with the huge amount of accumulated documents, which requires an optimal sophistication of classification schemes, as well a theoretical development of records/ documents organization.

Although the mentioned issue will not be focused on in this study, we will highlight the comparison made by Sousa, when he demonstrated (in 12 topics) the application of some requirements proposed by philosophy and classification theory to classification processes in archival science. Two of those processes were particularly important, as they demonstrated that (Sousa 2007b, 115):

- The classification pursues an end, an object, a goal. In the case of archives, it is the organization of records/documents;

- The classification in archives assumes a classifier agent, that is, the archivist.

We can conclude, therefore, that for the purpose of organizing documents or records, a "classifier agent" (i.e., one who acts, operates, practices the action), is necessary" and this agent has, in addition to a set of skills that enable him to this professional practice, a set of moral values, related to different social environments, influenced by economic and religious factors and by the individual professional qualification.

According to Lopez (2002), archival classification activities can only achieve their full goals through documentary description, and in order to build a description that an- 
swers and reflects the fonds the best possible way, it is necessary to begin simultaneously with the classification covering the record in its current phase and the document in its permanent phase. In addition, the finding aids generated from the description (guides, inventories, catalogs, indexes) must always be reviewed, keeping up to date, which shows that the acting of the archivist, is not, and cannot be something static, but a dynamic professional performance. For the author Heredia Herrera (1995, 300), the description can be viewed as "a bridge that communicates the document with their users," and the archivist is the professional on the head of this mediation, performing the task of ... analysis, which supposes identification, reading, condensation and indication to the user .... The archivist, consequently, acts as a dynamic professional both in classification and archival description and his/her professional performance is directly connected with his/her individual experience, which reflects his/her moral values. So, reflections on the values that come from this ethical universe are necessary

To this end, the analysis of 16 documents related to archivists' professional conduct were carried out, and identification of the values embodied in the activities of classification and description were analyzed.

\subsection{Results}

The following codes were identified in 10 countries, together with the International Council of Archives: Code of Ethics (Australian Society for Archivists-ASA, Australia); Princípios Éticos (Associação dos Arquivistas Brasileiros-AAB, Brazil), Code of Ethics (Association of Canadian Archivists-ACA, Canada); Code de déontologie (Association des Archivistes du Québec-AAQ, Canada); Code of Conduct: Values and Ethics (Library and Archives Canada-LAC, Canada); Code de déontologie (Association des Archivistes Français-AAF, France); Code of Ethics for the archives \& records association of NZ (Archives and Records Association of New Zealand-ARANZ, New Zealand); Código de Ética (Associação Portuguesa de Bibliotecários, Arquivistas e Documentalistas-APBAD, Portugal); Código deontológico de los archiveros catalanes (Associaó d' Arxivers de Catalunya, Spain); Code of Ethics for archivists (Association des Archivistes Suisses-AAS, Switzerland); Code of Conduct (Archives and Records Association-ARA, United Kingdom); Lord Chancellor's Code of Practice on the Management of Records under section 46 of The Freedom of Information Act 2000 (Ministry of Justice, United Kingdom); A Code of Practice on Archives for Museums and Galleries in the United Kingdom (Standing Conference on Archives and Museums-SCAM, United Kingdom); Role Delineation Statement (Academy of
Certified Archivists-ACA, United States); Core Values Statement and Code of Ethics (Society of American Archivists-SAA, United States); Code of Ethics (International Council on Archives ICA).

From the 16 selected documents, 5 (31\%) do not have the terms related to classification and description: BrazilAAB, Canada-AAQ, United States-SAA, New Zealand-ARANAZ and Portugal-APBAD. However 6 documents $(37 \%)$ presented both terms: Australia-ASA, Canada-ACA, United States-ACA, United KingdomARA, United Kingdom-Ministry of Justice, and Switzerland-AAS. The term related to classification appears in 4 documents (25\%): ICA/PT, France-ICA, Canada-LAC and United Kingdom-SCAM, and only1 document (6\%) has the term related to description: Spain- Associaó d'Arxivers de Catalunya.

Regarding archival arrangement, 10 codes considered this activity as a professional conduct: International Council of Archives, France-AAF, Australia-ASA, CanadaACA, Cana-LAC, United States-ACA, United Kingdom-ARA, United Kingdom-MJ, United KingdomSCAM, and Switzerland-AAS. In this context, the following ethical values were identified: information access, respect for provenance, respect for the original order, respect for the preservation of the archival value of the record, physical preservation of the record, conservation, access and use, information security, reliability, authenticity, custody and impartiality. If any of these values is not identified in the archival arrangement, ethical problems can emerge. For instance, if the archivist chooses to use a subject to arrange the records instead of applying the principle of provenance, the original order and the fonds can be lost and the reliability of information can be compromised.

Authenticity can also be compromised because the classification scheme must reflect the functions and structures of the entity that creates the records. When a subject scheme is used, these functions and structures are not represented and the record cannot be considered a faithful representation of the facts that it testifies. Regarding archival description, 7 codes considered this activity as a professional conduct: Australia-ASA, Canada-ACA, United States-ACA, United KingdomARA, United Kingdom-MJ, Spain-AAC, and Switzerland-AAS. In this context, the following ethical values were identified: physical preservation of the records, information access, respect for provenance, respect for the original order, custody, information security, conservation, reliability, and impartiality. These values can be found when the archivist uses international rules for archival description, such as ISAD (G) and ISAAR (CPF). These rules allow a standardized description, respecting the original order and the principle of provenance as well as all the aforementioned values. 
A. Pachú da Silva, J. A. Chaves Guimarães, N. Bolfarini Tognoli. Ethical Values in Archival Arrangement and Description

\begin{tabular}{|c|c|c|}
\hline Country & Values related to arrangement & Values related to description \\
\hline Australia / ASA & $\begin{array}{l}\text { Respect for the preservation of the archival } \\
\text { value of the record } \\
\text { Information access. }\end{array}$ & $\begin{array}{l}\text { Physical preservation of the record } \\
\text { - Information access }\end{array}$ \\
\hline Canada / ACA & Access and use & - Custody \\
\hline Canada / LAC & $\begin{array}{l}\text { Information security } \\
\text { Confidentiality } \\
\text { Information access } \\
\end{array}$ & - \\
\hline France/ AFF & $\begin{array}{l}\text { Respect for provenance } \\
\text { Respect for the original order } \\
\text { Respect for the preservation of the archival } \\
\text { value of the record }\end{array}$ & - \\
\hline Spain / Associaó d' Arxivers de Catalunya & - & - Conservation \\
\hline Switzerland / AAS & $\begin{array}{l}\text { Physical preservation of the record } \\
\text { Conservation } \\
\text { Information access }\end{array}$ & $\begin{array}{l}\text { Respect for provenance } \\
\text { - Respect for the original order } \\
\text { - Custody } \\
\text { - Physical preservation of the record } \\
\text { - Impartiality } \\
\end{array}$ \\
\hline United Kingdom / ARA & $\begin{array}{l}\text { Respect for provenance } \\
\text { Respect for the original order } \\
\text { Physical preservation of the record } \\
\text { Conservation } \\
\text { Impartiality }\end{array}$ & $\begin{array}{l}\text { Respect for provenance } \\
\text { - Respect for the original order } \\
\text { Physical preservation of the record } \\
\text { Information access }\end{array}$ \\
\hline United Kingdom / Ministry of Justice & $\begin{array}{l}\text { Reliability } \\
\text { Information access } \\
\text { Physical preservation of the record } \\
\text { Authenticity }\end{array}$ & $\begin{array}{l}\text { Physical preservation of the record } \\
\text { - Reliability } \\
\text { - Information security }\end{array}$ \\
\hline United Kingdom / SCAM & Custody & - \\
\hline United States / ACA & $\begin{array}{l}\text { Respect for provenance } \\
\text { Respect for the original order } \\
\text { Information access }\end{array}$ & $\begin{array}{l}\text { Respect for provenance; } \\
\text { - Respect for the original order } \\
\text { - Information access }\end{array}$ \\
\hline ICA / International Council on Archives & $\begin{array}{l}\text { Respect for provenance } \\
\text { Respect for the original order } \\
\text { Respect for the preservation of the archival } \\
\text { value of the record }\end{array}$ & - \\
\hline
\end{tabular}

Table 1. Comparative table of values related to classification and description. (Source: Elaborated by the authors.)

\begin{tabular}{|c|l|c|c|}
\hline Position & Values & Number of documents & \%* \\
\hline $1^{\circ}$ & Information access & 6 & 55 \\
\hline $2^{\circ}$ & Respect for provenance & 5 & 45 \\
\hline $3^{\circ}$ & Respect for the original order & 5 & 45 \\
\hline $4^{\circ}$ & Physical preservation of the record & 4 & 36 \\
\hline $5^{\circ}$ & Conservation & 3 & 27 \\
\hline $6^{\circ}$ & Respect for the preservation of the archival value of the record & 3 & 27 \\
\hline $7^{\circ}$ & Reliability & 2 & 18 \\
\hline $8^{\circ}$ & Custody & 2 & 18 \\
\hline $9^{\circ}$ & Information security & 2 & 18 \\
\hline $10^{\circ}$ & Impartiality & 2 & 18 \\
\hline $11^{\circ}$ & Authenticity & 1 & 9 \\
\hline $12^{\circ}$ & Confidentiality & 1 & 9 \\
\hline $13^{\circ}$ & Access and use & 1 & 9 \\
\hline
\end{tabular}

Table 2. Ranking of values. (Source: Elaborated by the authors.)

Based on these values, we elaborated the ranking shown in Table 2.

From a comparative analysis of the values involved in arrangement and description, we observed that the value attached to access to information had the highest overall frequency (55\%). Following this value, we found respect for provenance and original order (45\% each), confirming the essentiality of these principles as a basis for archival 
knowledge organization. Next, we found the values related to physical preservation of the record $(36 \%)$ and Conservation $(27 \%)$ reflecting the professional ethical commitment with the maintenance of the fonds integrity in the organization process. It is also important to point out that the incidence of respect for the preservation of the archival value of the record $(27 \%)$ reaffirms what Schellenberg (2006) defines as a double value of the archival records: the administrative value and the historical value.

From the 13 values identified, the following 3 are repeated in Rego et al. (2014): respect for provenance, impartiality and authenticity. In order to understand the real importance of each value identified in the codes of ethics, their applicability within the functions of arrangement/classification and description are presented:

- Information access: this value is directly related to the function of description, once it aims to give access to the information related to the context of records creation and its content. This access is given by the finding aids and standards of archival description, final stages in the process of organization and representation of archival knowledge.

- Respect for provenance and respect for the original order: as mentioned before, the respect for provenance is the main principle for classifying archival records/documents. When the archivist chooses for classifying the records based on its provenance and activities, and not on its subject, he/she guarantees the respect for the principle of original order, not committing its reliability as faithful record of the activities of institutions.

- Physical preservation and conservation of the record: these values are connected with archival description when the archivist creates finding aids that replace the document, representing its story and content, so the user does not have to have direct access to it, which also ensures its integrity. The preservation and conservation is also presented in the moment of physical storage, when the archivist chooses installations and procedures that ensures the safeguard of documents.

- Respect for the preservation of the archival value of the record: the archival value of record is related to its use. The first use of a record is related to its creation, with the use the creator does of it. It is called administrative value, or primary use. The second use is related to its use for other people, and it is called historical value or secondary use. The archivist should know how to recognize these values in the moment of classification, so he/she can stipulate the guard deadlines for it, and elaborate the evaluation and description instruments.

- Reliability: although the codes of ethics refer to the reliability of creation of the records (external reliability), it is also important to consider the reliability of the activities of classification and description (internal reliability), when the archivist uses his/her "power to name" (Olson 2002).

- Custody: this value is intrinsically connected with the function of archival description, once it regards with the guard and protection of documents by the entity that has the juridical responsibility for it. The guard and protection of the documents is done through its physical and intellectual organization and is reflected on the finding aids elaborated to replace the documents and to recreate its contexts and relationships.

- Information security: the security of information is guaranteed by the archivist when he/she classifies documents that should be protected and kept in secret, and when he/she describes only the information that can be disclosed, in the moment of description, omitting data that cannot be disclosed for any reason.

- Impartiality: the archivist should aim to be impartial in his/her professional practice, to offer his service to all, since his performance stems from a power given to him/her by society. This search for impartiality should always be oriented to facilitate the access to the documents to the largest number of users, issues understood related to cultural diversity (Delmas 2010, Beghtol 2002).

- Authenticity: when classification schemes reflect the functions and structures of the entity that creates the records through a faithful representation of the facts, in order to testify it. When this faithful representation is present on classification, authenticity value is reached.

- Confidentiality: when the archivist ensures the safeguard of any archival information, which has been previously protected by law.

- Access and use: this value is directly linked with the description functions, since it is the moment they can be considered as mediating activities that aim to give access to archival information, in addition to make the use of this information possible.

Guimarães et al (2008) identified a group of 23 articles whose contents were related to the ethical question in KOR and grouped the values in three spheres:

a) Superior values which must guide all the information activity;

b) Values previously recognized as professional requirements because they are essential to the action of an information professional; and,

c) Values previously considered as mere information retrieval measures, but recognized today as part of the axiological universe of KOR. 
A. Pachú da Silva, J. A. Chaves Guimarães, N. Bolfarini Tognoli. Ethical Values in Archival Arrangement and Description

Based on Guimarães et al. (2008), we noticed that the values identified in our study can also be inserted in these spheres as follows:

- Superior values which must guide all the information activity: information access, respect for provenance, respect for the original order, physical preservation of the record, conservation, respect for the preservation of the archival value of the record, reliability, custody, information security, authenticity, confidentiality, access and use.

- Values previously recognized as professional requirements because they are essential to the action of an information professional: impartiality and confidentiality.

\subsection{Conclusion}

Ethical issues are strongly perceived in relation to the professional practice regarding archival arrangement and description. This reveals that the professional associations of archivists assume ethical issues as inherent of the entire process of organization and representation of information. The concluded values confirm the results previously obtained by Guimarães et al. (2008) regarding librarians' practice (access to information, reliability, information security, reliability and easiness of use) and Rego et. al. (2014) and also includes new specific values related to the archival practice such as respect for the provenance, respect for the original order, physical preservation of the record, conservation, respect for the preservation of the archival value of the record, and custody. These aspects show maturation in the archival professional legislation, since such deontological dimensions seem to be strongly grounded on a solid axiological substrate of the area.

\section{References}

Angel, Christine. 2013. "A Comparison of Descriptive Tagging Practices by Library, Archive, and Museum: Professionals Using an Inter-Indexing Consistency Approach." In Transition, Cultures, Transition KO: Evolving Exploration, Critical Reflection, and Practical Work: Proceedings of the 4th North American Symposium on Knowledge Organization, 13-14 June 2013, Milwankee, WI., 1-10. http:// www.iskocus.org/nasko2013proceedings/angel_interi ndexingpaper.pdf.

Australia. Australian Society for Archivists (ASA). "Code of Ethics.” http://www.archivists.org.au/page/about/ code_of_ethics/.

Bardin, Laurence. 2009. "L'analyse de Contenu." 7.Ed. Paris: PUF.
Barros, Thiago H. B. and Moraes, João B. E. 2012. "Archival Classification and Knowledge Organization: Theorical Possibilities for the Archival Field". In Categories, Contexts and Relations in Knowledge Organization: Proceedings of the Twelfth International ISKO Conference August 6-9, 2012, Mysore, India, edited by A. Neelameghan and K. S. Raghavan. Advances in Knowledge Organization 13. Würzburg: Ergon-Verlag, pp. 272-6.

Beghtol, Clare. 2002. "Universal Concepts, Cultural Warrant, and Cultural Hospitality”. In: Challenges in Knowledge Representation and Organization for the 21 Century: Integration of Knowledge across Boundaries, edited by M. J. López-Huertas, 45-9. Wurzburg: Ergon-Verlag.

Brazil. Associação Dos Arquivistas Brasileiros (AAB). "Princípios Éticos." http://www.aab.org.br/?page_id $=27$.

Canada. Association Des Archivistes Du Québec (AAQ). "Code De Déontologie." http://www.archivistes.qc. ca/a-propos/code-de-deontologie.

Canada. Association of Canadian Archivists (ACA). "Code of Ethics." http://archivists.ca/content/code-ethics.

Canada. Library and Archives Canada (LAC). "Code of Conduct: Values and Ethics.” http://www.bac-lac.gc.ca/ eng/about-us/pages/code-conduct-value-ethics.aspx.

Delmas, Bruno. 2010. Arquivos Para Que? São Paulo: Instituto Fernando Henrique Cardoso (Ifhc).

Duchein, Michel. 1983. "Theoretical Principles and Practical of Respect Dês Fonds in Archival Science." Archivaria 16: 64-82.

Foscarini, Fiorella. 2006. "Records Classification and Functions: An Archival Perspective." Knowledge Organization 33: 188-98.

France. Association Des Archivistes Français (AAF). "Code De Déontologie." http://www.archivistes.org/ code-de-deontologie.

Gilliland, Anne J. 2006. "Contemplating Co-Creator Rights in Archival Description.” Knowledge Organization 33: 340-6.

Guimarães, José A. C., Juan C. Fernández-Molina, Fábio A. Pinho and Suellen O. Milani. 2008. "Ethics in the Knowledge Organization Environment: An Overview of Values and Problems in the LIS Literature." In Culture and identity in knowledge organization: Proceedings of the Tenth International ISKO Conference, August 5-8, 2008, Montréal, Canada, edited by C. Arsenault and J. T. Tennis. Advances in Knowledge Organization 11. Würzburg: Ergon-Verlag, pp. 361-6.

Henttonen, Pekka. 2012. "Diversity of Knowledge Organization in Records and Archives Management." In Categories, Contexts and Relations in Knowledge Organization: Proceedings of the Twelfth International ISKO Conference August 6-9, 2012, Mysore, India, edited by A. Neelameghan 
and K. S. Raghavan. Advances in Knowledge Organization 13. Würzburg: Ergon-Verlag, pp. 277-83.

Henttonen, Pekka. 2014. "Bibliographic Subject Headings as Access Points to Archival Sources." In Knowledge Organization in the 21st Century: Between Historical Patterns and Future Prospects: Proceedings of the Thirteenth International ISKO Conference, 19-22 May 2014, Krakón, Poland, edited by Wieslaw Babik. Advanced in Knowledge Organization 14. Würzburg: Ergon-Verlag, pp. 461-8.

ICA. International Council on Archives (ICA). "Code of Ethics.” http:/ / www.ica.org/?lid=5555\&bid=225.

Lopez, André Porto Ancona. 2002. Como descrever documentos de arquivo: Elaboração de instrumentos de pesquisa. São Paulo: Arquivo do Estado, Imprensa Oficial.

$\mathrm{NCH}$, "History." Network of Concerned Historians. http://www.concernedhistorians.org/content_files/file /va/h.pdf.

New Zealand. Archives and Records Association of New Zealand (ARANZ). "Code of Ethics for the Archives \& Records Association Of NZ." http://www.aranz. org.nz/site/about_aranz/code_of_ethics.aspx.

Portugal. Associação Portuguesa De Bibliotecários, Arquivistas E Documentalistas (APBAD). "Código De Ética.” http://www.apbad.pt/downloads/codigo_etica .pdf.

Rego, Laura M., Andrieli P. Silva, Daniel Martínez-Avila and Natália B. Tognoli. 2014. "Aspéctos Éticos De La Organización Del Conocimiento Em La Práctica Profesional Archivística: Un Estúdio De Lós Princípios Éticos De AAB, CIA Y SAA." Scire 20, no. 2: 37-42.

Ribeiro, Fernanda. 2014 "The Use of Classification in Archives as a Means of Organization, Representation and Retrieval of Information." Knowledge Organization 41, no. 4: 319-26.

Rousseau, Jean-Yves and Carol Couture. 1994. Les Fondements De La Discipline Archivistique. Sainte-Foy, Québec: Presses De l'Université Du Québec.

Schellenberg, Theodore R. 1996. Modern Archives: Principles and Techniques. Chicago: Society of American Archivists.

Spain. Associaó D’ Arxivers De Catalunya. “Código Deontológico De Los Archiveros Catalanes." http://www. arxivers.com/index.php/documents/publicacions / col-leccio-textos-1/textos-traduccions-1/130-textos-01codigo-deontologico-de-los-archiveros-catalanes-1/file.

Switzerland. Association Des Archivistes Suisses (AAS). "Code of Ethics for Archivists." http://www.vsa-aas. org/fr/beruf/code-of-ethics/.

Thomassem, Theo. 2001. "A First Introduction to Archival Science." Archival Science 1: 4-16.

Tognoli, Natália B. and José A. C. Guimarães. 2010. "Postmodern Archival Science and Contemporary
Diplomatics. New Approaches for Archival Knowledge Organization." In Paradigms and Conceptual Systems in Knowledge Organization: Proceedings of the Eleventh International ISKO Conference, 23-26 February 2010, Rome, Italy, edited by Claudio Gnoli and Fulvio Mazzocchi. Advances in Knowledge Organization 12. Würzburg: Ergon, 405-11.

Tognoli, Natália B. and José A. C. Guimarães, 2012. "Challenges of Knowledge Representation in Contemporary Archival Science.” In Categories, Contexts and Relations in Knowledge Organization: Proceedings of the Twelfth International ISKO Conference August 6-9, 2012, Mysore, India, edited by A. Neelameghan and K. S. Raghavan. Advances in Knowledge Organization 13. Würzburg: Ergon, 267-271.

Tognoli, Natália B., José A. C. Guimarães and Joseph T. Tennis, 2013. "Diplomatics As A Methodological Perspective For Archival Knowledge Oragnization." In Transition, Cultures, Transition KO: Evolving Exploration, Critical Reflection, and Practical Work: Proceedings of the 4th North American Symposium on Knowledge Organization, 1314 June 2013, Milwankee, WI. http://www.iskocus. org/nasko2013proceedings/tognoli_guimaraes_tennis _diplomaticsasamethodologicalperspective.pdf.

United Kingdom. Archives and Records Association (ARA). "Code of Conduct." http://www.archives.org. uk/images/documents/aracouncil/ara_code_of_con duct_final.pdf.

United Kingdom. Ministry of Justice. "Lord Chancellor's Code of Practice on the Management of Records Under Section 46 of the Freedom of Information Act 2000." http://www.justice.gov.uk/downloads/ infor mation-access-rights/foi/foi-section-46-code-of-prac tice.pdf.

United Kingdom. Standing Conference on Archives and Museums (SCAM). "A Code of Practice on Archives for Museums and Galleries in the United Kingdom." http://www.archivesandmuseums.org.uk/scam/code. pdf.

Unites States. Academy of Certified Archivists (ACA). "Role Delineation Statement." http://www.certified archivists.org $/ /$ ?s $=$ the $+2003+$ role + delineation + state ment+revision.

Unites States. Society of American Archivists (SAA). "Core Values Statement and Code of Ethics." http:// www2.archivists.org/statements/saa-core-values-state ment-and-code-of-ethics\#core_values.

Zhang, Jane. 2012. "Archival Context, Digital Content, and the Ethics of Digital Archival Representation." Knowledge Organization 33: 332-9. 